\title{
The Second Time Around: Status quo and Reform of the Europarties' Selection Procedures for Spitzenkandidaten in 2019
}

\author{
Wouter Wolfs \\ (KU Leuven)
}

\author{
Gert-Jan Put
(KULeuven) \\ Gert-Jan Put
(KULeuven)
}

June 2019
Steven Van Hecke

(KULeuven)

This is a preliminary draft.

Please do not cite or distribute without permission of the authors.

\begin{abstract}
In the run-up to the 2019 European Parliament elections, the main Europarties are again nominating a leading candidate for the presidency of the European Commission. These Spitzenkandidaten are subjected to the Europarties' internal selection procedures where they, in theory, compete with other high-profile co-partisan candidates for the nomination. In 2014, these intra-party candidate selections were organized in a relatively short span of time and ad-hoc manner due to a lack of preparation and experience (Put et al., 2016). The Europarties had to start designing procedures from scratch and had no tradition to lean upon as this was the first form of political recruitment taking place at the EU level.

In this contribution, we analyze whether, how and why the Europarties reformed their selection procedures regarding leading candidates for the 2019 European Parliament elections. Following the scholarly literature on candidate selection reforms by national political parties, we identify a set of political system-, party-and intraparty-level determinants that foster procedural reforms (Barnea and Rahat, 2007). The Europarties'selection procedures for leading candidates will be analyzed on the basis of official party documents (statutes, regulations) and semistructured elite interviews organized with party officials of four Europarties: European People's Party (EPP), the Party of European Socialists (PES), the Alliance of Liberals and Democrats for Europe Party (ALDE) and the European Green Party (EGP).

The analysis will focus on the four main dimensions of the central theoretical framework by Hazan and Rahat (2010): candidacy, selectorate, centralization and voting/appointment procedure. Additionally, we examine the level of internal competition during these procedures and the timing of the different procedural steps.
\end{abstract}




\section{Introduction}

Strasbourg, 15 July 2014. Jean-Claude is elected by the European Parliament as the new president of the European Commission. He had been the "Spitzenkandidat" or lead candidate of the European People's Party (EPP) in their electoral campaign for the European elections of 2014. It was the first time that the main European political parties had put forward their candidates for the presidency of the European Commission. A vote for one of the national member parties also became a choice for the lead candidates of their European political party. The EPP emerged from the European elections as the largest political force and - after an institutional struggle with the heads of the state and government in the European Council their lead candidate, Jean-Claude Juncker, became the new Commission President.

This "Spitzen-experiment" was repeated in the run-up to the European elections of 2019. This time, seven European political parties nominated Spitzenkandidaten to lead their European election campaign (Table 1): the five Europarties that also selected lead candidates in 204 (EPP, PES, ALDE Party, EGP and PEL), and two Europarties that participated in the Spitzenkandidaten process for the first time (ACRE and EFA).

Table 1: Overview of the lead candidates of the European political parties in the 2019 European elections

\begin{tabular}{|c|c|c|c|}
\hline European Political Party & Lead Candidate(s) & Country & National Party \\
\hline European People's Party (EPP) & Manfred Weber & Germany & CSU \\
\hline $\begin{array}{l}\text { Party of European Socialists } \\
\text { (PES) }\end{array}$ & Frans Timmermans & Netherlands & PvdA \\
\hline \multirow{7}{*}{$\begin{array}{l}\text { Alliance of } \\
\text { Democrats for } \\
\text { (ALDE) }\end{array}$} & Guy Verhofstadt & Belgium & Open VLD \\
\hline & Nicola Beer & Germany & FDP \\
\hline & Margrethe Vestager & Denmark & Radikale Venstre \\
\hline & Luis Garicano & Spain & Ciudadanos \\
\hline & Emma Bonino & Italy & +Europa \\
\hline & Violeta Bulc & Slovenia & SMC \\
\hline & Katalin Cseh & Hungary & Momentum \\
\hline \multirow{2}{*}{ European Green Party (EGP) } & Ska Keller & Germany & Grüne \\
\hline & Bas Eickhout & Netherlands & GroenLinks \\
\hline \multirow{2}{*}{ Party of the European Left (PEL) } & Violeta Tomic & Slovenia & Levica \\
\hline & Nico Cué & Belgium & No affiliation \\
\hline $\begin{array}{l}\text { Alliance of Conservatives and } \\
\text { Reformists in Europe (ACRE) }\end{array}$ & Jan Zahradil & Czech Republic & ODS \\
\hline European Free Alliance (EFA) & Oriol Junqueras & Spain & ERC \\
\hline
\end{tabular}

The Spitzenkandidaten process is not formally included in the regulatory framework of the European Union (EU), but follows from an expansive interpretation of Article 17(7) of the Lisbon Treaty:

"Taking into account the elections to the European Parliament and after having held the appropriate consultations, the European Council, acting by a qualified majority, shall propose to the European Parliament a candidate for President of the Commission. This candidate shall be elected by the European Parliament by a majority of its component members. If he does not obtain the required majority, the European Council, acting by a qualified majority, shall within one month propose a new candidate who shall be elected by the European Parliament following the same procedure" [ emphasis added]. 
The ambiguous wording of the treaty text has been used by the European Parliament - with support of the European Commission - to assert that the European political parties would select lead candidates for the presidency of the European Commission and that the candidate from the winning political group in the European Parliament is supposed to be elected by the MEPs as the new President of the European Commission (Hobolt, 2014, 1532; Braun \& Popa, 2018, 1125).

The aim of this paper is to analyze the procedures of the European political parties to select their lead candidates for the European elections in 2019. We will examine whether the European political parties have changed their selection procedures compared to the previous European elections in 2014, and how these reforms can be explained. We will apply a comparative approach and build on the theoretical insights from the literature on candidate selection procedures in national political parties. The analysis of the selection procedures is based on internal party documents (regulations, statutes, rules of procedures), complemented by a series of semi-structured interviews with members of the Europarties' leadership of the EPP, PES, ALDE Party and EGP.

Studying the selection procedures for the lead candidates contributes to our knowledge of European political parties as political organisations. For European political parties, the Spitzenkandidaten procedure has been one of the few tools to increase their impact on European decision-making. It is the only candidate selection procedure that is the sole prerogative of the Europarties. We will examine to what extent these European party organisations have gone through a "learning process", in which they adapt their internal procedures to a changing political context and which lessons are drawn from past experiences.

Such an analysis is also valuable from a more normative perspective. The position of Commission President is - as one of the "top jobs" in the EU institutions - at the helm of the European executive and he or she has substantial influence over the pace and direction of European policy. One of the main arguments in favour of the Spitzenkandidaten system has been that it strengthens the electoral link between the EC President and the European citizens and provides the positions with a stronger legitimation (Christiansen, 2016, 10061007; Hobolt, 2014). However, at the same time the impact of the Spitzenkandidaten procedure on the European elections remained small and knowledge about the lead candidates among voters was - apart from a number of exceptions - limited in most member states (Braun \& Schwarzbözl, 2019; Braun \& Popa, 2018; Schmitt, Hobolt \& Popa, 2015). Despite this limited recognisability and electoral link, the lead candidate of one of the European political parties did become the Commission President. Consequently, it is important to gain insight in how these European political parties select their Spitzenkandidaten and which considerations they take into account.

\section{Analytical Framework}

Political parties traditionally fulfill a whole range of functions that are beneficial to democracy (King, 1967; Hofmeister and Grabow 2011). One of these functions is the recruitment of political personnel and political leaders. Parties nominate candidates for parliamentary seats, and - usually drawing from this pool of candidates - select contenders for executive office. The characteristics of these selected candidates determines the strength of the legislative and executive branch, and consequently also the quality and stability of (representative) democracies (Gallagher \& Marsh, 1988). 
Political parties at the European level do not fulfill the functions that are traditionally assigned to political parties to the same extent as their national counterparts (Wolfs and Smulders, 2018, 183-186). Historically, the selection of political personnel is not a competence of the European political parties (Raunio, 2007; Bardi \& Calossi, 2013). The composition of the candidate lists for the elections of the European Parliament remains the prerogative of national parties, and the members of the European Commission are nominated by the governments of the member states and subsequently approved (or not) by the European Parliament.

The "Spitzenkandidaten procedure" signified an important change in this respect. Although the origins of this process date back to the beginning of the 1990s (Van Hecke, Wolfs \& De Groof, 2018), it was during the European elections of 2014 that the largest Europarties put forward their candidates for the presidency of the European Commission. This development created important candidate selection competences for the European political parties, as the candidate that was selected by the largest Europarty would become the head of the European executive. Consequently, the selection procedure that the European political parties have used is important, as it influences who has a chance to be appointed as Spitzenkandidat, and - potentially - president of the European Commission. During the elections of 2019, this Spitzenkandidaten procedure was repeated, and the European political parties again selected lead candidates to be at the forefront of their electoral campaigns. The main aim of this paper is to examine whether the Europarties have altered their selection procedures and what the main reasons were for these changes.

Barnea and Rahat (2007) developed an analytical framework to examine the reform of candidate selection methods of political parties. They distinguish three main levels (Table 2). The first is the political system level and comprises the general political context, and the norms and conventions of power distribution. In other words, the long-term social, cultural and political trends have an impact on the reform of candidate selection methods. Factors such as democratization or personalization of politics are expected to push political parties in a certain substantive direction regarding their reforms. The second level is the party system level, which refers to the competition between political parties. In other words, reforms of candidate selection procedures can be triggered by inter-party competitive factors, such as electoral loss or the emergence of new political competitors. In contrast to the first level, inter-party competition does not influence the direction or type of reforms, but the timing of the reforms that are conducted, according to Barnea and Rahat. Third, there is the intra-party level, in which the unit of analysis are individual politicians or certain factions within political parties. Changing (or preserving) candidate selection rules can be used by the party elite to protect their status and position. As such, reforms of the selection procedures can be caused by a change of party leadership, the merger or split of political parties, or the emergence of political challengers within the party.

Table 2: Reform of candidate selection methods: an analytical framework (Taken from Barnea and Rahat $(2007,378$ )

\begin{tabular}{|l|l|l|l|}
\hline Focal point & Political System Level & \multicolumn{1}{|c|}{ Party System Level } & \multicolumn{1}{c|}{ Intra-Party Level } \\
\hline $\begin{array}{l}\text { General cultural, } \\
\text { social and political } \\
\text { environment }\end{array}$ & $\begin{array}{l}\text { Interactions (mainly } \\
\text { competition) between } \\
\text { political parties }\end{array}$ & $\begin{array}{l}\text { Interactions between } \\
\text { individuals, factions and } \\
\text { party groupings }\end{array}$ \\
\hline $\begin{array}{l}\text { Unit(s) of } \\
\text { analysis }\end{array}$ & $\begin{array}{l}\text { Norms and } \\
\text { conventions }\end{array}$ & $\begin{array}{l}\text { Parties as unitary } \\
\text { actors }\end{array}$ & $\begin{array}{l}\text { Individuals, factions and } \\
\text { other possible intra-party } \\
\text { groupings }\end{array}$ \\
\hline
\end{tabular}




\begin{tabular}{|l|l|l|l|}
\hline $\begin{array}{l}\text { Contribution to } \\
\text { the explanation }\end{array}$ & $\begin{array}{l}\text { - Direction of reform } \\
\text { - Politically } \\
\text { admissible range of } \\
\text { choice of candidate } \\
\text { selection methods }\end{array}$ & $\begin{array}{l}\text { - Timing of reform } \\
\text { initiation }\end{array}$ & $\begin{array}{l}\text { - Evolution of the specific } \\
\text { initiated reform }\end{array}$ \\
\hline $\begin{array}{l}\text { Possible } \\
\text { Relevant Factors }\end{array}$ & $\begin{array}{l}\text { - Democratization } \\
\text { - Personalization } \\
\text { - Americanization }\end{array}$ & $\begin{array}{l}\text { - Electoral Failure } \\
\text { - Damage to the party's } \\
\text { public image } \\
\text { - Electoral Competition } \\
\text { - Government turnover }\end{array}$ & $\begin{array}{l}\text { - Leadership contest and } \\
\text { succession } \\
\text { - Party merger or split } \\
\text { - Power struggle between } \\
\text { challengers and } \\
\text { apparatchiks }\end{array}$ \\
\hline
\end{tabular}

Applying theories and concepts from the study of national political parties to European political parties is not necessarily a straightforward exercise and is related to the general discussion on the sui generis nature of the European Union. Some scholars have indeed expressed reservations about the comparability of the EU because it is not an international organization, nor a state (see Bressanelli 2014, 34). However, Mair (2005) has argued that we should consider the European Union as a political system, which allows us to apply concepts and theories that were developed for a domestic context to the European Union. Although there still are significant differences between national and European parties, these Europarties still share sufficient features with their national counterparts and several scholars have applied concepts from (national) party research to European political parties (Bressanelli 2014; Lord 2010; Lightfoot 2006; Külahci and Lightfoot 2014; Johansson 2015, Put et al, 2016).

For the purpose of this research, we have "translated" the analytical framework of Barnea and Rahat to the situation of European political parties (Table 3). At the political system level, two main factors can be distinguished to explain reforms of the selection procedure for the Spitzenkandidaten. First, the debate on the alleged democratic deficit of the European Union and need for further democratization. Advocates of the Spitzenkandidaten system have argued that this would turn the EU political system into a quasi-parliamentary system that increases democratic accountability. Spitzenkandidaten would "raise the stakes of the vote, personalize the electoral campaign, enhance the European dimension of the election campaign, and thus to attract more voters to the polls and create a clearer democratic mandate for the European Commission" (Hobolt, 2014, 1532).

At the same time, the Spitzenkandidaten system has also influenced the inter-institutional relations in the European Union. The European Parliament has used the ambiguous wording of a treaty article strategically to increase its influence over the selection of the Commission President at the expense of the member states in the European Council (Hobolt, 2014, 15321533; Christiansen, 2016). As such, the Spitzenkandidaten system is embedded in the broader inter-institutional dynamics of the European Union.

Table 3: Reform of selection methods of the Spitzenkandidaat by European political parties: an analytical framework

\begin{tabular}{|c|c|c|c|}
\hline & Political System Level & Party System Level & Intra-Party Level \\
\hline Focal point & $\begin{array}{l}\text { General cultural, } \\
\text { social and political } \\
\text { environment of the } \\
\text { European Union. }\end{array}$ & $\begin{array}{l}\text { Interactions (mainly } \\
\text { competition) between } \\
\text { European political } \\
\text { parties }\end{array}$ & $\begin{array}{l}\text { Interactions between } \\
\text { individuals, factions and } \\
\text { party groupings }\end{array}$ \\
\hline
\end{tabular}




\begin{tabular}{|l|l|l|l|}
\hline $\begin{array}{l}\text { Unit(s) of } \\
\text { analysis }\end{array}$ & $\begin{array}{l}\text { Norms and } \\
\text { conventions }\end{array}$ & $\begin{array}{l}\text { Parties as unitary } \\
\text { actors }\end{array}$ & $\begin{array}{l}\text { Individuals, factions and } \\
\text { other possible intra-party } \\
\text { groupings (member } \\
\text { parties) }\end{array}$ \\
\hline $\begin{array}{l}\text { Possible } \\
\text { Relevant Factors }\end{array}$ & $\begin{array}{l}\text { - Democratization } \\
\text { - Personalization } \\
\text { - Inter-institutional } \\
\text { dynamics }\end{array}$ & $\begin{array}{l}\text { - Electoral Failure } \\
\text { - Damage to the party's } \\
\text { public image } \\
\text { - Electoral Competition }\end{array}$ & $\begin{array}{l}\text { - Leadership contest and } \\
\text { succession } \\
\text { - Europarty membership } \\
\text { changes. } \\
\text { - Change to composition } \\
\text { and competences of party } \\
\text { bodies }\end{array}$ \\
\hline
\end{tabular}

The second level consists of three party-level factors. First, the electoral performance (of the Spitzenkandidat) in the last European elections can be an important trigger to reform the selection procedure. A poor performance of the candidate could raise questions about the appropriateness of the existing selection method to produce the most successful candidate. Second, if the way the Spitzenkandidat was selected has caused damage to the public image of the Europarty, this could provide an impetus for reform. Third, European political parties can look to their political opponents and learn from them in terms of selection process, or adjust the timing of their procedure in function of the competitor's timing.

At the intra-party level, three factors can be distinguished. First, a change in the Europarty leadership can be a cause of a change of the selection procedure. Second, member parties can leave the European party organization or new parties can join, which can influence the way that the Spitzenkandidat is selected. Third, the organizational structure of the European political party could be adapted, with changes to the composition and competences of the various party bodies, which can in turn lead to an alteration of the candidate selection procedure.

\section{The Second Time Around: the selection procedure of the European political parties in 2014 and 2019}

In the following paragraphs, we will give an overview of the evolution of the selection procedures of the European political parties to nominate their lead candidate. Table 4 gives an overview of these procedures in 2014 and 2019 for the EPP, PES, ALDE Party and EGP, based on the four dimensions of the theoretical framework by Hazan and Rahat (2010). 
Table 4: Selection Procedures to nominate the Spitzenkandidaten of the EPP, PES, ALDE Party and EGP in 2014 and 2019

\begin{tabular}{|c|c|c|c|c|c|c|c|c|}
\hline & \multicolumn{2}{|c|}{ EPP } & \multicolumn{2}{|c|}{ PES } & \multicolumn{2}{|c|}{ ALDE } & \multicolumn{2}{|c|}{ EGP } \\
\hline & 2014 & 2019 & 2014 & 2019 & 2014 & 2019 & 2014 & 2019 \\
\hline Candidacy & $\begin{array}{l}\text { Support by own } \\
\text { national party }+ \\
\text { maximum two other } \\
\text { member parties }\end{array}$ & $\begin{array}{l}\text { Support by own } \\
\text { national party }+ \\
\text { maximum two other } \\
\text { member parties }\end{array}$ & $\begin{array}{l}\text { Support by } 15 \% \text { of full } \\
\text { member parties (incl. } \\
\text { own party or other } \\
\text { party from own } \\
\text { country) }\end{array}$ & $\begin{array}{l}\text { Support by } 25 \% \text { of full } \\
\text { member parties or } \\
\text { organi-sations (incl. } \\
\text { own party or other } \\
\text { party from own } \\
\text { country) }\end{array}$ & $\begin{array}{l}\text { Support by at least } \\
\text { two member } \\
\text { parties (from } \\
\text { different countries) } \\
\text { or } 20 \% \text { of congress } \\
\text { delegates }\end{array}$ & $\begin{array}{l}\text { [Support by at least two } \\
\text { member parties (from } \\
\text { different countries) or } \\
\text { 20\% of congress } \\
\text { delegates] } \\
\text { Unclear in practice }\end{array}$ & $\begin{array}{l}\text { Support by at least } \\
\text { four and max. eight } \\
\text { member parties }\end{array}$ & $\begin{array}{l}\text { Nomination by one } \\
\text { party and } \\
\text { additional support } \\
\text { of at least five } \\
\text { additional member } \\
\text { parties }\end{array}$ \\
\hline Selectorate & $\begin{array}{l}828 \text { EPP delegates at } \\
\text { electoral congress }\end{array}$ & $\begin{array}{l}758 \text { EPP delegates at } \\
\text { electoral congress }\end{array}$ & $\begin{array}{l}405 \text { PES delegates at } \\
\text { electoral congress }\end{array}$ & $\begin{array}{l}339 \text { PES delegates at } \\
\text { electoral congress }\end{array}$ & $\begin{array}{l}388 \text { ALDE delegates } \\
\text { at electoral } \\
\text { congress }\end{array}$ & $\begin{array}{l}\text { XX ALDE delegates at } \\
\text { electoral congress } \\
\text { XX ALDE Party Council } \\
\text { Members }\end{array}$ & $\begin{array}{l}\text { EU citizens above the } \\
\text { age of } 16\end{array}$ & $\begin{array}{l}\text { 108 EGP Council } \\
\text { Members }\end{array}$ \\
\hline Decentralization & $\begin{array}{l}\text { Number of votes for } \\
\text { member parties: } \\
\text { three + number } \\
\text { depending on result } \\
\text { in last European } \\
\text { election }\end{array}$ & $\begin{array}{l}\text { Number of votes for } \\
\text { member parties: } \\
\text { three + number } \\
\text { depending on result } \\
\text { in last European } \\
\text { election }\end{array}$ & $\begin{array}{l}\text { Number of votes for } \\
\text { member parties based } \\
\text { on combination of } \\
\text { party strength in } \\
\text { national parliament, } \\
\text { European parliament } \\
\text { and country size }\end{array}$ & $\begin{array}{l}\text { Number of votes for } \\
\text { member parties based } \\
\text { on combination of } \\
\text { party strength in } \\
\text { national parliament, } \\
\text { European parliament } \\
\text { and country size }{ }^{1}\end{array}$ & $\begin{array}{l}\text { Number of votes for } \\
\text { member party } \\
\text { delegations } \\
\text { depends on party } \\
\text { strength in national } \\
\text { parliaments }\end{array}$ & $\begin{array}{l}\text { Number of votes for } \\
\text { member party } \\
\text { delegations depends on } \\
\text { party strength in } \\
\text { national parliaments } \\
\text { Number of votes } \\
\text { depends on party result } \\
\text { in last EU elections }\end{array}$ & $\begin{array}{l}\text { One man one vote- } \\
\text { no weights for } \\
\text { member parties or } \\
\text { countries }\end{array}$ & $\begin{array}{l}\text { Number of votes for } \\
\text { member parties } \\
\text { based on } \\
\text { combination of } \\
\text { party strength in } \\
\text { national parliament } \\
\text { and European } \\
\text { parliament }\end{array}$ \\
\hline $\begin{array}{l}\text { Voting or } \\
\text { appointment } \\
\text { procedures }\end{array}$ & $\begin{array}{l}\text { Absolute majority of } \\
\text { valid votes by EPP } \\
\text { delegates } \\
\text { (abstentions not } \\
\text { valid) }\end{array}$ & $\begin{array}{l}\text { Absolute majority of } \\
\text { valid votes by EPP } \\
\text { delegates } \\
\text { (abstentions not } \\
\text { valid) }\end{array}$ & $\begin{array}{l}\text { Qualified majority of } \\
\text { valid votes by PES } \\
\text { delegates }\end{array}$ & $\begin{array}{l}\text { Absolute majority of } \\
\text { valid votes by PES } \\
\text { delegates (in two } \\
\text { rounds if necessary) }\end{array}$ & $\begin{array}{l}\text { Absolute majority } \\
\text { of valid votes by } \\
\text { ALDE delegates (in } \\
\text { two rounds if } \\
\text { necessary) }\end{array}$ & $\begin{array}{l}\text { Absolute majority of } \\
\text { valid votes by ALDE } \\
\text { delegates (in two rounds } \\
\text { if necessary) } \\
\text { Simple majority with } \\
\text { minimum } 1 / 3 \text { of } \\
\text { delegates present }\end{array}$ & $\begin{array}{l}\text { Relative majority of } \\
\text { selectorate; two } \\
\text { winning candidates } \\
\text { cannot be of same sex } \\
\text { or member state }\end{array}$ & $\begin{array}{l}\text { Absolute majority } \\
\text { of votes }\end{array}$ \\
\hline Outcome & $\begin{array}{l}\text { - Jean-Claude Juncker } \\
\text { - Michel Barnier } \\
\text { - Valdis } \\
\text { Dombrovskis* }\end{array}$ & $\begin{array}{l}\text { - Manfred Weber } \\
\text { - Alexander Stubb }\end{array}$ & - Martin Schulz & $\begin{array}{l}\text { - Frans Timmermans } \\
\text { - Maros Sefcovic* }\end{array}$ & $\begin{array}{l}\text { - Guy Verhofstadt } \\
\text { - Olli Rehn* }\end{array}$ & $\begin{array}{l}\text { - Nicola Beer } \\
\text { - Emma Bonino } \\
\text { - Violeta Bulc } \\
\text { - Katalin Cseh } \\
\text { - Luis Garicano } \\
\text { - Guy Verhofstadt } \\
\text { - Margrethe Vestager }\end{array}$ & $\begin{array}{l}\text { - José Bové } \\
\text { - Ska Keller } \\
\text { - Monica Frassoni } \\
\text { - Rebecca Harms }\end{array}$ & $\begin{array}{l}\text { - Bas Eickhout } \\
\text { - Ska Keller } \\
\text { - Petra De Sutter } \\
\text { - Atanas Schmidt }\end{array}$ \\
\hline
\end{tabular}

Text in italic (ALDE Party) represents the formal requirements, which does not correspond to how the procedure was conducted in practice

- $\quad$ Candidates in bold are the selected Spitzenkandidaten. Candidates with an asterisk withdrew their candidacy before selection took place.

1 The number of weighed votes for each member party is calculated using the following formula: ((percentage of MPs in the lower chamber of the national parliament + number of MEPs) x number of votes of the country in the (European) Council) rounded up / 45 (See Articles 20.6 and 22.1. of the PES Statutes, as adopted by the $10^{\text {th }}$ PES Congress on 12 June 2015) 


\subsection{European People's Party}

The Spitzenkandaten process of 2014 was seen as a positive experience within the EPP. Not only had its lead candidate Jean-Claude Juncker been elected as president of the European Commission, the Europarty's internal selection procedure was also positively evaluated (Interview A). The procedure for 2014 was determined on a rather ad hoc basis during the EPP's Meise Summit in December 2013. During the first congress after the 2014 elections that took place in October 2015 in Madrid, the selection of the EPP lead candidate was enshrined in the party statutes. These rules now included that the EPP's Political Assembly was responsible for accepting the candidatures to become the Europarty's lead candidate and that the election of this Spitzenkandidaat was the sole responsibility of the EPP Congress. ${ }^{2}$ This formal change demonstrated the strong political support that existed within the Europarty to continue with the Spitzenkandidaten process after the 2014 elections (Interview A).

The details of the selection of the lead candidate for the 2019 elections were determined by the EPP's Political Assembly in April and September 2018 (European People's Party, 2018a, 3 ). The procedure itself was not substantially changed compared to 2014 . Concerning the candidate dimension, a candidate required the formal support of his or her own national party and a maximum of two additional member parties from other EU countries than the candidate's country of origin. Only the presidents or the secretary-generals of the member parties were entitled to nominate or endorse a candidate (European People's Party, 2018b). The ceiling of three supporting member parties was chosen deliberately to avoid a race between the candidates to gain the support of as many member parties as possible (Put et al, 2016, 14; L. Vandeputte, personal communication, November 14, 2014; Interview A).

The selectorate and voting procedure were neither changed compared to 2014: the candidate that received the absolute majority of votes - not counting abstentions - of the delegates on the EPP's electoral congress, was nominated as the EPP's candidate for Commission President. The selectorate was relatively extensive: a total of 758 delegates of the 49 EPP member parties, 6 associate member parties, 6 member associations, 14 individual MEPs and delegations from European and international institutions are tasked with determining the Europarty's Spitzenkandidaat (European People's Party, 2018e), which is a form of a selected party agency (Kenig, 2009, 436).

The only aspect that was changed about the procedure, was the timeline, which was changed on two main points. First, the period between the opening of the candidatures and the vote on the electoral congress was made longer. This allowed for a stronger involvement of the EPP's government leaders, as the candidates could be received at the EPP summit (Interview A). This can be explained by the experiences of 2014: despite the fact that it was Jean-Claude Juncker had gained the most support in the European Parliament, some of the strongest opposition against his nomination as Commission President originated from German Chancellor Angela Merkel and European Council President Herman Van Rompuy, both members of the EPP (Hobolt, 2014, 1537; Keating, 2014). Although the EPP government leaders do not have a specific statutory function in the internal selection process of the

\footnotetext{
${ }^{2}$ Articles 16 and 18 of the Statutes of the Euroepan People's Party, as approved by the EPP Congress on $21^{\text {st }}$ of October 2015 in Madrid.
} 
Europarty, their stronger involvement could increase their support for the Spitzenkandidaten process in general, and the EPP's lead candidate in particular.

Second, the entire time table was brought forward a couple of months. Whereas Jean-Claude Juncker had only been nominated in March 2014, barely two months before the European elections, the EPP chose to advance the process for the 2019 elections and nominate a candidate before the end of 2018. Selecting the candidate before the end of 2018 provided more time to prepare the electoral campaign and to involve the national member parties in more directly targeting the voters in the various member states (Interview A). This was also the reason why the electoral manifesto of the EPP was only decided in March 2019, which allowed the nominated Spitzenkandidat to gather input from the member parties and to put his or her mark on the policy platform of the Europarty. This was also different in 2014, when the EPP's manifesto had already been decided when Jean-Claude Juncker was put forward as the Europarty's lead candidate.

The call for candidacies was opened on 6 September 2018 and candidates had the time until 17 October 2018 to gain the required support of their own party and two other EPP member parties. Two candidates gained the required support: Manfred Weber and Alexander Stubb. The two candidates were invited to the EPP Summit on 17 October 2018 in Brussels, where they presented themselves to the EPP government leaders (European People's Party, 2018d). Although formally candidates could only declare the support of their own party and a maximum of two additional parties, Manfred Weber built a support base that was as broad as possible. He secured the endorsements of seven of the eight EPP heads of state (Austria, Bulgaria, Croatia, Cyprus, Germany, Ireland and Romania); only Hungarian prime minister Viktor Orban refused to endorse Manfred Weber. Weber had sought this explicit approval among the government leaders anticipating their required support in the European Council after the European elections. Additionally, Weber was supported by the EPP member parties from the Netherlands, Greece and Slovenia (de La Baume, 2018). Consequently, although the formal rules wanted to avoid a contest in gathering as many endorsements as possible of the member parties, in practice this was circumvented by collecting informal signs of support.

Considering the many informal endorsements, it is no surprise that Manfred Weber managed to win the nomination as EPP lead candidate fairly easy. On the electoral Congress, 492 of the 619 valid votes $(79,5 \%)$ were cast in support of Weber, and 127 delegates (20,5\%) voted for Alexander Stubb (European People's Party, 2018c; Stolton \& Fortuna, 2018). In the European elections of 2019, the EPP emerged as the largest political force in the European Parliament, which - in theory - strengthens the prospects of Manfred Weber to become the next Commission President.

\subsection{Party of European Socialists}

Also within the Party of European Socialists, the Spitzenkandidaten process of 2014 was positively evaluated. In analogy to the nomination last time, the PES Council decided to established a "Working Group Common Candidate 2019" consisting of delegates from all member parties and organisations to work out the timeline and (democratic and transparent) procedure to nominate the lead candidate (Party of European Socialists, 2017). This early involvement characterized the Europarty's commitment to the Spitzenkandidaten process. It echoes the main aim of the Europarty that had been voiced in the PES Roadmap 2019 that was adopted on the party congress in Budapest in 2015: "Our main challenge [...] is to win the European elections and to become the first group in the European Parliament in 
2019 and have our common candidate elected as European Commission President" (Party of European Socialists, 2015a, 4).

The nomination process for the 2019 elections was prepared by the new Working Group Common Candidate and approved by the PES Presidency in June 2018 (Party of European Socialists, 2018a). Regarding the candidate dimension, the threshold for candidatures was raised: where candidates were required to gather the support of 15 per cent of the member parties during the selection process of 2014 (including the candidate's own party), this was raised to 25 per cent for 2019 (Party of European Socialists, 2011, 2; Party of European Socialists, 2018a, 2). Since a member party or organisation could only support one potential candidate, this meant in practice that the support of 9 parties or organisations was required for a successful candidature (Party of European Socialists, 2018a, 2). ${ }^{3}$ The higher threshold was installed to make sure that only "serious" candidates that already enjoyed substantial support within the Europarty would put forward their candidature. This would also limit the risk of a fierce (and thus damaging) internal contest, in order to end up with a lead candidate that is uncontested within the European political party (Interview B).

The selectorate and voting procedure were (potentially) expanded compared to 2014. The official nomination of the lead candidate would take place on the PES Election Congress, where all full member parties and organisations had a number of delegates depending on their representation in the national and European Parliament, and the size of the country (Party of European Socialists, 2015b, 8-9). All member parties could determine how their delegates would vote according to their own internal decision-making procedures, and the votes needed to be distributed proportionally among the various candidates depending on the result of the internal party decision-making process. A novelty was the possibility to directly consulting PES party members through internal (open) primaries (Party of European Socialists, 2018a, 1-3). In other words, member parties could organize public election procedures to determine how its delegates would have to vote on the PES Election Congress. The use of primaries had been put forward by the Southern delegation within the PES (mainly Italy and Spain) (Interview B). All results of the internal decision-making process would be made public on a "PES European Election Day", a week before the PES Election Congress (Party of European Socialists, 2018a, 2-3). The main purpose of these changes was to generate public and media attention. It appears that inspiration was drawn from the US example, where primaries are organised in each state to determine the support for each of the party candidates for the US presidency, in which the PES Election Congress would function as a type of "Party Convention" as was custom in the US.

Compared to the previous European elections, the nomination process was started a few months earlier. Martin Schulz had only been nominated in February 2014, which had left little time for the preparation and implementation of the electoral campaign. For the 2019 elections, there had been some debate internally to determine the timing of the nomination of the lead candidate on a PES Congress. Suggestions to have a Spitzenkandidat by the summer of 2018 were declined, because this would discourage potential strong candidates like European Commissioners or heads of government, because they would not been able to combine their PES candidacy with their function (Interview B). In other words, setting the nomination date too early might decrease the quality of candidates. The end of 2018 was

\footnotetext{
${ }^{3}$ Anno 2018, the PES had 33 full member parties and 5 full member organisations (Party for European Socialists, 2018a, 2).
} 
considered a good compromise, as it limited the period that someone had to make his or her candidacy public, but it left sufficient time to properly prepare the electoral campaign (Interview B).

For the 2019 European elections, the call for candidatures was opened at 1 October 2018. By the closing date of 18 October 2018, two candidates had gathered sufficient letters of nomination from the member parties: Frans Timmermans (Netherlands, PvdA) and Maros Sefcovic (Slovakia, Smer). A third candidate had insufficient support among the PES member parties and was therefore not taken into consideration for the nomination (Interview B). On the fifth of November 2018, Maros Sefcovic dropped out of the race and endorsed Frans Timmermans (Party of European Socialists, 2018b), after support among the member parties for Timmermans appeared to be more substantial (Interview B). Because only one candidate remained, the PES did not organize a Europe-wide Election Day as foreseen, to avoid that some of the member parties would not endorse Frans Timmermans which would jeopardize party unity (Interview B).

\subsection{Alliance of Liberals and Democrats for Europe Party}

The Spitzenkandidaten procedure received mixed evaluations within the Alliance of Liberals and Democrats for Europe Party. On the positive side, it was seen as a good instrument to bring the European Union closer to the citizens. However, There was also criticism within the Europarty that it was not a real process as it had not been possible to vote for the lead candidate in the whole of Europe, or that is had not even been compulsory to stand for election in any EU member state, as was the case with Jean-Claude Juncker, who was not a candidate in his home country Luxembourg. Furthermore, ALDE Party Members rejected the interpretation of the Spitzenkandidaten system that it would always be the biggest party family in the European Parliament that would be entitled to the Commission presidency (Interview C).

Despite these mixed feelings, the ALDE Party did develop a procedure to nominate one lead candidate for the European elections of 2019, which was basically a codification of the process that had already been followed in the run-up to the 2014 elections. In 2014, the possibility of nominating a Spitzenkandidat was not included in the Europarty's statutes, which meant that it was the competence of the Bureau (Interview C). This put a small group of people in charge of picking a candidate. It was circumvented through a resolution stating that the Bureau would automatically nominate the person that was put forward by the electoral congress of the Europarty, paving the way for a broader involvement of the member party delegates. In 2015 this was institutionalized, by amending the statutes stipulating that the election of "a common top candidate(s) for the European election" was restrictively reserved to the Congress (Alliance of Liberals and Democrats for Europe Party, 2015a, 5). For this purpose, the voting procedure to elect the ALDE Party President was used: a majority of more than 50 percent of the votes cast was required (not counting abstentions, blank or invalid votes). In case no candidate obtained a majority, a second round would be organized between the two candidates who obtained the most votes. For the election of the lead candidate, only full member parties and individual members from EU Member States could vote (Alliance of Liberals and Democrats for Europe Party, 2015b, 4-5).

Although a procedure to nominate a lead candidate was codified fairly rapidly after the 2014 European elections, reservations about the Spitzenkandidaten system remained a point of discussion in the ALDE Council meetings, and several changes to the procedure were 
considered (open primaries, online vote, etc.) to mitigate the criticism and make the process more open and democratic (Interview C). In the course of 2018, an increasing number of ALDE Members voiced their concerns about nominating only one lead candidate, as this would create a strategic disadvantage compared to the two biggest Europarties, EPP and PES. Because of the perceived logic of the Spitzenkandidaten process that the biggest party family is entitled to the Commission presidency, the chances for the ALDE Party to obtain this post were very slim indeed. A catalytic factor in this respect was the rejection of transnational lists by the European Parliament in February 2018 (Hardy, 2018), a proposal that enjoyed substantial support among the liberal parties. Within the ALDE Party, many shared the position that a Spitzenkandidaten system without transnational lists would mean that the liberal party family would be locked in a system that was designed to benefit (mainly) the EPP (Interview C).

Consequently, support grew to move away from onelead candidate and put forward a diverse group of people to show the "different facts of European liberalism" in terms of age, gender, geography and various ideological traditions within the ALDE Party, an idea first proposed at the ALDE summit of prime ministers and Commissioners (Interview C). During the ALDE Party Council Meeting in Madrid in November 2018, the formal decision was taken to conduct an electoral campaign with a full "team" of candidates (de La Baume, 2018). The task to compose this group of candidates was delegated to ALDE Party President Hans van Baalen. He had to make a proposal by the Spring of 2019 that would be adopted by the Council (Interview C).

ALDE President van Baalen mainly consulted with liberal prime ministers to put together the list of candidates. The proposal of President van Baalen was formally endorsed by the ALDE Party Council in March 2019 (Alliance of Liberals and Democrats for Europe Party, 2019). The liberal "Team Europe" consisted of seven politicians: Nicola Beer (Germany, FDP), Emma Bonino (Italy, Più Europa), Violeta Bulc (Slovenia, SMC), Katalin Cseh (Hungary, Momentum), Luis Garicano (Spain, Ciudedanos), Guy Verhofstadt (Belgium, Open VLD) and Margrethe Vestager (Denmark, Radikale Venstre). The selection of these candidates also served a political strategic purpose: by nominating a young Hungarian candidate, the ALDE Party hoped to increase her (national party's) visibility and electoral chances.

\subsection{European Green Party}

Within the European Green Party, some reservations existed regarding the candidate selection procedure that had been used in 2014. In the run-up to those European elections, the EGP had launched an online open primary in which four candidates contested for the position of Green lead candidate (Put et al, 2016, 16). Although the procedure itself was evaluated positively, the participation rate had been disappointing: in total 22676 participated in the online primary (European Green Party, 2014b, 1). For the 2019 elections, the use of an open online primary was considered again, but due to the lukewarm response of the member parties, the proposal was abandoned. The leadership of the European Green Party held the opinion that an online primary could not be successful without the active engagement of the green member parties. During preparatory meetings for the 2019 elections, it became clear that the support of the member parties for another online primary was rather low, so a new procedure had to be developed (Interview D).

As had been the case in 2014, the new candidate selection procedure was proposed by the EGP Committee - which consisted of two co-chairpersons of the Europarty, the Secretary- 
General, the Treasurer and five additional committee members (European Green Party, 2018a, 13) - and subsequently adopted by the EGP Council in May 2018 (European Green Party, 2018b). In analogy to 2014, the Council decided that the EGP would participate in the 2019 European elections with two lead candidates, of which at least one had to be eligible for election. In case of eligibility, they were also required to stand for election on an electoral list of one of the EGP member parties (European Green Party, 2018b, 1).

Regarding the candidate dimension, the selection procedure would take place in two steps. First, candidates could be nominated by their own party by 14 September 2018. Interestingly, national parties were also allowed to put forward non-members as candidates (European Green Party, 2018b, 1). Then, in a second step, the candidates had an additional two weeks to gain the support of five additional member parties. Green member parties were allowed to support two candidates. The threshold of five member parties was seen as a good balance between keeping it sufficiently low to foster the participation of as many candidates as possible on the one hand, and preventing individuals to participate simply to advance their own career on the other hand (Interview D). A vote on the (eligible) candidates would take place during the EGP Council at the end of November 2018 (European Green Party, 2018b, 12). A candidate required to obtain an absolute majority of the votes in order to get elected (European Green Party, 2018c, 1).

The timing of the entire selection procedure was changed: whereas the two lead candidates were only nominated in January 2014, the two lead candidates for the 2019 elections would already be elected in November 2018. This was mainly done for external and internal organisational reasons. The EGP anticipated that the EPP would nominate their candidate in the beginning of November and the Socialists in December, so it was important to elected the green Spitzenkandidaten during the same period. Additionally, a Council meeting was already scheduled for that period; organising an additional meeting or Congress early 2019 would put a financial burden on the EGP and its member parties (Interview D).

By the deadline of 14 September 2018, four candidates had been put forward by their member party: Petra De Sutter, nominated by Groen (Belgium), Bas Eickhout nominated by GroenLinks (Netherlands), Ska Keller nominated by Bündnis 90/Die Grünen (Germany) and Atanas Schmidt, nominated by Zelena Partija (Bulgaria) (European Green Party, 2018d). Only the first three received sufficient support to compete for the two lead candidate positions; 4 support for the candidacy of Atanas Schmidt fell below the threshold of six member parties (European Green Party, 2018e). In the vote during the EGP Council meeting in Berlin in November 2018, Ska Keller finished first with more than 50 per cent of the votes

\footnotetext{
${ }^{4}$ Petra De Sutter was supported by 8 additional member parties: Ecolo (Belgium), Vihreät - De Gröna (Finland), EELV (France), Comhaontas Glas (Ireland), Fed. dei Verdi (Italy), déi gréng (Luxembourg), Zieloni (Poland) and Green Party of England and Wales (UK). Bas Eickhout was supported by 12 additional member parties: Die Grünen (Austria), Zelenite (Bulgaria), Zelení (Czech Rep.), SF (Denmark), Eestima Erakond Rohelised (Estonia), Bündnis 90/Die Grünen (Germany), Ecologists Greens (Greece), Verdi/Grüne/Vërc (Italy), Partido Ecologista - Os Verdes (Portugal), Partidul Verde (Romania), SMS Zeleni (Slovenia) and miljöpartiet de gröna (Sweden). Ska Keller was supported by 24 additional member parties: Die Grünen (Austria), Groen (Belgium), Zelenite (Bulgaria), ORaH (Croatia), Cyprus Green Party (Cyprus), Zelení (Czech Rep.), SF (Denmark), Eestima Erakond Rohelised (Estonia), Vihreät - De Gröna (Finland), EELV (France), Ecologists Greens (Greece), Comhaontas Glas (Ireland), Fed. dei Verdi (Italy), Verdi/Grüne/Vërc (Italy), déi gréng (Luxembourg), Alternattiva Demokratika (Malta), GroenLinks (Netherlands), Zieloni (Poland), Partido Ecologista - Os Verdes (Portugal), Partidul Verde (Romania), EQUO (Spain), ICV (Spain), miljöpartiet de gröna (Sweden), Green Party of England and Wales (UK) and FYEG (Europe).
} 
in the second round. ${ }^{5}$ In the run-off for the second lead candidate position, Bas Eickhout won 62 per cent of the votes and beat Petra De Sutter (Posaner, 2018).

\section{Discussion}

The four analysed European political parties have all - to a small or large extent - altered aspects of their internal selection procedure. Considering the empirical analysis in the previous paragraphs, it becomes clear that the factors identified at the three levels (political system, party system and intra-party level) have played a role in this process (Table 5).

The European People's Party prolonged its procedure to strengthen the involvement of the Europarty's heads of state and government, which is related to the inter-institutional dynamics between the EU institutions. While the EPP's lead candidate, Jean-Claude Juncker, gained substantial support in the European Parliament in 2014, the most outspoken opposition against his nomination as EC President came from some of his EPP colleagues, German Chancellor Angela Merkel and European Council President Herman Van Rompuy. By involving the EPP heads of state early in the nomination process, the EPP hoped to avoid a similar scenario in 2019. This strategy was also conducted by Manfred Weber, who sought the (informal) endorsement of the EPP government leaders in order to be able to fall back on it after the European elections. Regarding the party system level, the earlier timeline was also aimed at a better preparation of the electoral campaign to compete against the other European political parties. At the intra-party level, the ad hoc selection procedure had been included in the Europarty rules shortly after the 2014 elections in order to counter any opposition from within the European political party - for example among the government leaders - against the Spitzenkandidaten system.

Table 5: Factors that have influenced the changes to the selection procedures of the four European political parties in 2019

\begin{tabular}{|c|c|c|c|}
\hline & Political System Level & Party System Level & Intra-Party Level \\
\hline EPP & $\begin{array}{l}\text { Timeline changed: increase } \\
\text { involvement of EPP } \\
\text { government leaders }\end{array}$ & $\begin{array}{l}\text { Timeline changed: provide } \\
\text { more time to prepare } \\
\text { electoral campaign }\end{array}$ & $\begin{array}{l}\text { Internal selection procedure of lead } \\
\text { candidate codified in statutes: } \\
\text { prevent that Spitzenkandidaten } \\
\text { system is questioned internally }\end{array}$ \\
\hline PES & & $\begin{array}{l}\text { Open primaries and “Election } \\
\text { Day": generate visibility } \\
\text { Timeline changed: provide } \\
\text { more time to prepare } \\
\text { electoral campaign }\end{array}$ & $\begin{array}{l}\text { Candidate threshold raised: lower } \\
\text { risk of internal contests and } \\
\text { preserve party unity } \\
\text { Annul “Election Day" (ad hoc): } \\
\text { preserve party unity }\end{array}$ \\
\hline $\begin{array}{l}\text { ALDE } \\
\text { Party }\end{array}$ & $\begin{array}{l}\text { Procedure changed (ad hoc): } \\
\text { stronger involvement of } \\
\text { liberal prime ministers }\end{array}$ & $\begin{array}{c}\text { Selection of multiple } \\
\text { candidates (ad hoc): } \\
\text { delegitimize lead candidates } \\
\text { of EPP (and PES) } \\
\end{array}$ & $\begin{array}{l}\text { Selection of multiple candidates (ad } \\
\text { hoc): avoid internal division over } \\
\text { selection of one candidate }\end{array}$ \\
\hline EGP & & $\begin{array}{l}\text { Timeline changed: taking into } \\
\text { account political competitors }\end{array}$ & $\begin{array}{l}\text { Procedure changed: Low support } \\
\text { of green member parties for an } \\
\text { open primary }\end{array}$ \\
\hline
\end{tabular}

\footnotetext{
5 The second round was a run-off between the two candidates that received the most votes in the first voting round: Ska Keller received 45,5\%, Bas Eickhout 33,3\% and Petra De Sutter 19,2\% (Interview D).
} 
In case of the Party of European Socialists, mainly factors from the party system and the intraparty level seem to have influenced reforms of the selection procedure. As was the case with the EPP, the PES had advanced its selection procedure in order to have more time for a proper preparation of the electoral campaign. Additionally, it had included some novelties in the procedure - open primaries and a Europe-wide "Election Day" - to increase visibility and capture media attention. At the intra-Party level, preserving party unity was one of the main party objectives. To this end, the thresholds for candidacies was raised in order to avoid polarising candidacies that could jeopardize internal party cohesion. Similarly, when only candidate remained in the process - Frans Timmermans - it was decided to annul the "Election Day", as this could only weaken the position of the Spitzenkandidat (if some member parties would refuse to formally endorse the candidate).

The Alliance of Liberals and Democrats for Europe Party went to an interesting evolution. Whereas the Europarty had initially codified the ad hoc selection procedure for the lead candidate shortly after the 2014 elections, it changed its course in the run-up to the 2019 elections for strategic reasons. Instead of nominating one lead candidate, the Europarty decided to put forward a team of seven liberal politicians to campaign across Europe. As such, the party challenged the legitimacy of the Spitzenkandidaten procedure and, as such, also the chances of the lead candidates of the two biggest party families - EPP and PES - to become EC President. At the same time, nominating a group of candidates instead of one also avoided any potential internal party rifts. This had been the case in 2014, when a gridlock between Guy Verhofstadt and Olli Rehn had to be defused by two mediators (Mark Rutte and Christian Lindner). During the ad hoc and informal selection of the ALDE Party candidates, the liberal prime ministers gained a stronger role than they would have had in case of the nomination of only one Spitzenkandidat, potentially increasing their support in the post-election phase for one of the liberal candidates in the European Council.

The procedural change of the European Green Party was most substantial, altering their candidate selection procedure from an open online primary system to a much more closed system in which the Spitzenkandidaten are nominated by a limited group of member party representatives. The main reason for this change had been the limited support of these member parties to organize another open primary. Large support among the green member parties was also within the EGP considered of absolute importance, as the Europarty was totally dependent on its national parties to conduct its electoral campaign. A second change was more motivated by a party system factor: the entire selection procedure was advanced in order to follow the planned timeline of the other main European political parties. 


\section{References}

\section{Academic Studies}

Bardi, Luciano \& Enrico Calossi (2013), “"Normal” versus European Party Democracy: Some Theoretical Reflections", paper presented at the ECPR General Conference, Science Po Bordeaux, 4-7 September.

Barnea, Shlomit \& Rahat, Gideon (2007), "Reforming Candidate Selection Methods: A Three-Level Approach", Party Politics, 3 (13), 375-394.

Braun, Daniela \& Popa, Sebastian (2018), "This time it was different? The salience of the Spitzenkandidaten system among European parties", West European Politics, 5(41), 1125-1145.

Braun, Daniela \& Schwarzbözl, Tobias (2019), "Put in the spotlight or largely ignored? Emphasis on the Spitzenkandidaten by political parties in their online campaigns for European elections", Journal of European Public Policy, 3 (26), 428-445.

Bressanelli, Edoardo (2014), Europarties After Enlargement: Organization, Ideology and Competition, Basingstoke: Palgrave Macmillan.

Christiansen, Thomas (2016), "After the Spitzenkandidaten: fundamental change in the EU's political system?", West European Politics, 5 (39), 992-1010.

Gallagher, Michael, \& Marsh, Michael (Eds.) (1988), The secret garden of politics: Candidate selection in comparative perspective, London: Sage.

Hobolt, Sara (2014), "A vote for the president? The role of Spitzenkandidaten in the 2014 European parliament elections", Journal of European Public Policy, 21(10) 1528 - 40.

Hofmeister, Wilhelm, Karsten Grabow (2011), Political Parties: Functions and Organisation in Democratic Societies, Singapore: Konrad Adenauer Stiftung.

Johansson, Karl Magnus (2015), Europarties - a research note, Bonn: Zentrum für Europäische Integrationsforschung.

Kenig, Ofer (2009), "Democratization of party leadership selection: Do wider selectorates produce more competitive contests?”, Electoral Studies, 28(2), 240-247.

King, Anthony (1967), "Political Parties in Western Democracies: Some Sceptical Reflections", Polity, 2 (2), 111-41.

Külahci, Erol, and Simon Lightfoot (2014), "Governance, Europarties and the challenge of democratic representation in the EU: A case study of the Party of European Socialists." Acta Politica, 49(1), 71-85.

Lightfoot, Simon (2006), “The Consolidation of Europarties? The 'Party Regulation' and the Development of Political Parties in the European Union", Representation, 42(4), 303-314.

Lord, Christopher (2010), "The aggregating function of political parties in EU decision-making", Living Reviews in European Governance, 5(3), 1-33.

Mair, Peter (2005), "Popular Democracy and the European Union Polity", IDEAS Working Paper Series from RePEc. 
Raunio, Tapio (2007), "Political Parties in the European Union", in Knud Erik Jørgensen, Mark Pollack and Ben Rosamond (eds.), The SAGE Handbook of European Union Politics, London: Sage Publications, 247-262.

Schmidt, Hermann, Hobolt, Sara \& Popa, Sebastian (2015), "Does personalization increase turnout? Spitzenkandidaten in the 2014 European Parliament elections", European Union Politics, 16(3), 347-368.

Van Hecke, Steven, Wolfs, Wouter \& De Groof, Victor (2018), "25 Years of Spitzenkandidaten: What Does the Future Hold?", Wilfried Martens Centre for European Studies Policy Brief, November 2018.

Wolfs, Wouter, and Jef Smulders (2018) "Party finance at the level of the European Union. Party finance reform to vitalize the EU's protoparty system?", in Jonathan Mendilow and Eric Phélippeau (eds.), Handbook of Political Party Funding, London: Edward Elgar", 182-202.

\section{Party Documents}

European People's Party (2018a), Voting Regulation Adopted by the EPP Political Assembly, 6-7 September 2018, Helsinki, 7-8 November 2018.

European People's Party (2018b), Press Release: Political Assembly unveils EPP Congress preparations and opens the Spitzenkandidat application procedure; adopts resolution on Libya, Brussels, 7 September 2018.

European People's Party (2018c), Press Release: Manfred Weber elected as EPP candidate for the President of the European Commission, Helsinki, 8 November 2018.

European People's Party (2018d), Press Release: Brexit and Spitzenkandidat Procedure Top EPP Summit Discussions, Brussels, 17 October 2018.

European People's Party (2018e), EPP Congress Helsinki 2018: Votes per delegation as approved by the Political Assembly on 4-5 June 2018, Helsinki, 26 October 2018.

Party of European Socialists (2011), PES Resolution: Selecting our common candidate in 2014, Brussels, 24 November 2011.

Party of European Socialists (2015a), PES Roadmap toward 2019, Budapest, 12 \& 13 June 2015.

Party of European Socialists (2015b), PES Statutes, Budapest, 12 \& 13 June 2015.

Party of European Socialists (2017), PES Council Resolution: PES 2019 Common Candidate roadmap, Lisbon, 1 December 2017.

Party of European Socialists (2018a), Selecting the PES Common Candidate in 2019, Brussels, 20 June 2018.

Party of European Socialists (2018b), PES unites behind Timmermans as Lead Candidate for 2019 European elections, Brussels, 5 November 2018.

Alliance of Liberals and Democrats for Europe Party (2015a), Statutes of the Alliance of Liberals and Democrats for Europe Party aisbl, Budapest, 21 November 2015.

Alliance of Liberals and Democrats for Europe Party (2015b), Internal Regulations of the ALDE Party, AISBL, Budapest, 19 November 2015. 
Alliance of Liberals and Democrats for Europe Party (2019), Team Europe: seven leaders to renew Europe, Brussels, 21 March 2019.

European Green Party (2014a), Evaluation of the Common Campaign for the 2014 European Elections, Istanbul, 7-9 November 2014.

European Green Party (2014b), Annex to the Political Evaluation of the Common Campaign 2014 European elections, Istanbul, 7-9 November 2014.

European Green Party (2018a), Statutes of the European Green Party European Political Party (PPEU), Berlin, 25 November 2018.

European Green Party (2018b), Procedure for the 2019 Green leading candidates Spitzenkandidaten, Antwerp, 18-20 May 2018.

European Green Party (2018c), Draft Voting List, Berlin, 23-25 November 2018.

European Green Party (2018d), Four Greens enter race to become European Green Party leading candidates, Brussels, 17 September 2018.

European Green Party (2018e), Contenders Green leading candidates, Brussels, 29 September 2018.

\section{Media Articles}

Dave Keating, "No commitment from Van Rompuy to choose one of the five candidates for Commission presidency", European Voice, 16 May 2014.

Catherine Hardy, "EU Parliament rejects transnational lists”, Euronews, 7 February 2018.

Maia de La Baume, "Manfred Weber gets support for Commission top job from EPP leaders", Politico, 17 October 2018.

Samuel Stolton \& Gerardo Fortuna, "Weber wins EPP Spitzenkandidat in landslide victory", EurActiv, 8 November 2018.

Maia de La Baume, "Liberals to present slate of candidates for top EU jobs", Politico, 9 November 2018.

Joshua Posaner, "European Greens pick favourites for European Commission president", Politico, 24 November 2018.

\section{Interviews}

Interview A: Policy Advisor of the European People's Party (EPP) in Brussels, 16 April 2019. Interview B: Policy Advisor of the Party of European Socialists (PES) in Leuven, 4 June 2019. Interview C: Policy Advisor of the Alliance of Liberals and Democrats for Europe Party (ALDE Party) in Brussels, 27 March 2019.

Interview D: Policy Advisor of the European Green Party (EGP) in Brussels, 31 January 2019. 